\title{
Note
}

\section{Preparation of $S-\left(N^{6}, N^{6}\right.$-dimethyladenosyl)-L-methionine}

KONDAREDdiaR RAMalingam AND Ronald W. WOODARD

College of Pharmacy, The University of Michigan, Ann Arbor, Michigan 48109 (U.S.A.)

(Received March 8th, 1984; accepted for publication in revised form, November 5th, 1984)

During recent studies to delineate the structural features of the adenine moiety of $S$-adenosyl-L-methionine necessary to produce maximal activity in the enzyme 1-aminocyclopropane-1-carboxylic acid synthase ${ }^{1}$ (ACC-S), we required ( \pm$) S$ - $\left(N^{6}, N^{6}\right.$-dimethyladenosyl)-L-methionine (5). This compound has been previously reported ${ }^{2}$ as a possible substrate and/or inhibitor of the transmethylase enzymes catechol $O$-methyltransferase, phenylethanolamine $N$-methyltransferase, histamine $N$-methyltransferase, and hydroxyindole $O$-methyltransferase. However, no physical properties of the compound were reported and the physical properties of the precursor $S$ - $\left(N^{6}, N^{6}\right.$-dimethyladenosyl)-L-homocysteine ${ }^{3}(4)$ were suspect when compared with other $S$-adenosyl-L-homocysteine derivatives in which the adenosine had been modified.

Although $N^{6}, N^{6}$-dimethyladenosine [6-dimethylamino-9-( $\beta$-D-ribofuranosyl)purine, 2] is commercially available, it is expensive $(\$ 250 / \mathrm{g}$, Sigma). We therefore started the synthesis with inosine (9- $\beta$-D-ribofuranosylhypoxanthine), which was converted in two steps into 6-chloro-9-( $\beta$-D-ribofuranosyl)purine (1) via dimethyl chloromethyleneammonium chloride by the method of Zemlička ${ }^{4}$. The chloro derivative was converted into $N^{6}, N^{6}$-dimethyladenosine 2 in $92 \%$ yield by a modification of the procedure of Zemlička ${ }^{5}$. The original method reported a yield of $50 \%$. Other routes to 2 involve methylation of adenosine either reductively with $\mathrm{NaBH}_{4} / \mathrm{HCHO}$ in $65 \%$ yield 6 or directly with trimethylphosphate-tetrabutylammonium fluoride in $55 \%$ yield ${ }^{7} . N^{6}, N^{6}$-Dimethyladenosine was converted into $5^{\prime}$-chloro-5'-deoxy- $N^{6}, N^{6}$-dimethyladenosine (3) by the method of Ichino ${ }^{8}$. The key step in this synthesis is the displacement of chloride by the monosodium salt of L-homocysteine. This method has been used in our laboratory for the preparation of similar analogues 9 . The sulfonium salt was prepared by treatment of $S$ - $\left(N^{6}, N^{6}\right.$-dimethyladenosyl)-L-homocysteine (4) with methyl iodide and silver acetate in acetic acid-formic acid ${ }^{10}$. Purification of the sulfonium salt was accomplished by $\mathrm{C}_{18}$ reverse-phase low-pressure chromatography with the product eluting off with $0.1 \mathrm{M}$ ammonium acetate ( $\mathrm{pH} 3.5$ ) near the void volume. 


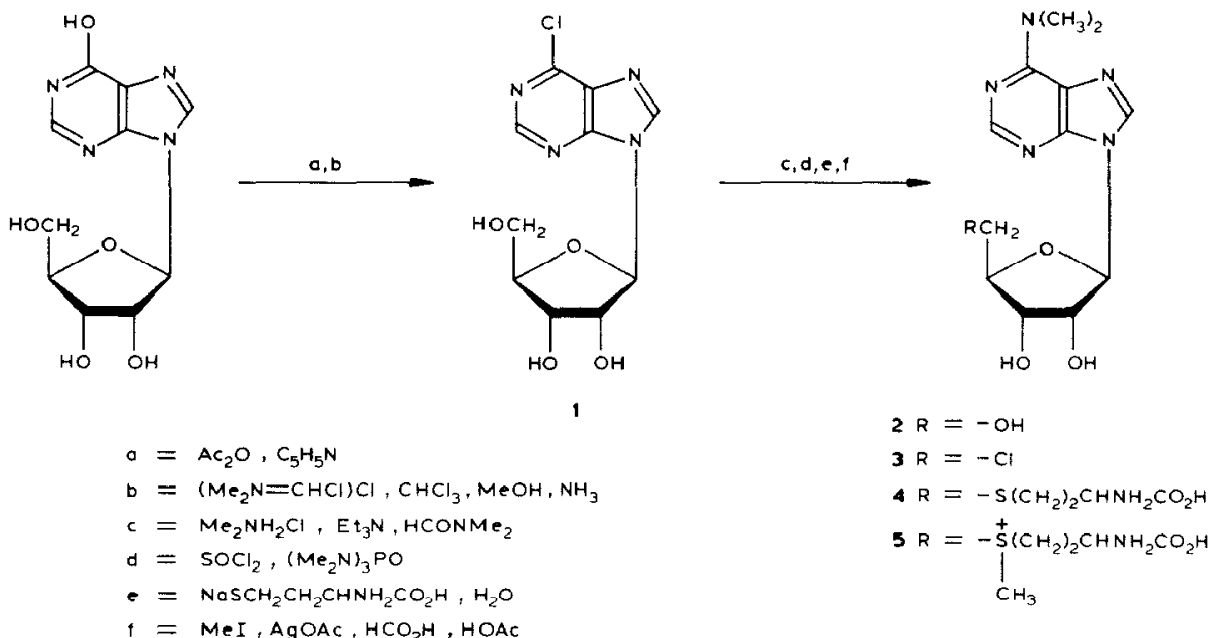

The procedure reported here allows the preparation of large amounts of the important biological compound 2, a key intermediate in the synthesis of several biologically interesting nucleotide analogues, as well as the synthesis of $S$ - $\left(N^{6}, N^{6}\right.$-dimethyladenosyl)-L-homocysteine (4) and the title compound, $S$ - $\left(N^{6}, N^{6}\right.$-dimethyladenosyl)-L-methonine (5).

\section{EXPERIMENTAL}

General methods. - Melting points were determined with a Mel-Temp capillary melting-point apparatus and are uncorrected. ${ }^{1}$ H-N.m.r. spectra were recorded with a Bruker WH-360 $(360-\mathrm{MHz})$ spectrometer. Chemical shifts are reported in p.p.m. downfield from tetramethylsilane in organic solvents and sodium 4,4-dimethyl-4-silapentanoate in $\mathrm{D}_{2} \mathrm{O}$. Elemental analyses were conducted by M-H-W Laboratories, Phoenix, Arizona. Specific rotations were recorded with a Perkin-Elmer model 141 polarimeter. Low-pressure chromatography was performed on a $\mathrm{C}_{18}$ reverse-phase column (Applied Science; Adsorbosil LC, 200-

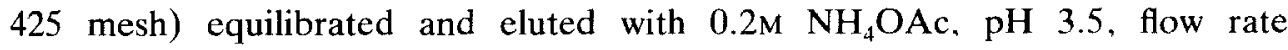
$10 \mathrm{~mL} / \mathrm{min}$; u.v. detector (260-nm wavelength monitor).

$\mathrm{N}^{6}, \mathrm{~N}^{6}$-Dimethyladenosine (2). - A mixture of 6-chloro-9-( $\beta$-D-ribofuranosyl)purine $\mathrm{f}^{4}(1,8.60 \mathrm{~g}, 0.03 \mathrm{~mol})$ and dimethylamine hydrochloride $(12.23 \mathrm{~g}$, $0.15 \mathrm{~mol}$ ) (dried over $\mathrm{H}_{2} \mathrm{SO}_{4}$ ) in $N, N$-dimethylformamide $(50 \mathrm{~mL}$ ) was stirred vigorously for $0.5 \mathrm{~h}$ at $0^{\circ}$. Triethylamine $(20.24 \mathrm{~g}(28.0 \mathrm{~mL}), 0.2 \mathrm{~mol})$ was then added and the mixture was stirred for an additional $2 \mathrm{~h}$ at $0^{\circ}$ and then for $15 \mathrm{~h}$ at room temperature. Triethylamine hydrochloride that formed was filtered off and washed with ice-cold $N . N$-dimethylformamide $(15 \mathrm{~mL}) . N, N$-Dimethylformamide was removed in vacuo $\left(0.5 \mathrm{~mm} \mathrm{Hg}\right.$ at $\left.45^{\circ}\right)$ and the residue was triturated with acetone $(150 \mathrm{~mL})$ to give $8.2 \mathrm{~g}(92.6 \%)$ of 2 . Crystallization of this product from 
methanol afforded $7.5 \mathrm{~g}(84.6 \%)$ of 2 having m.p. $183-184^{\circ}$ (lit. ${ }^{5}$ m.p. 182-185 $)$; ${ }^{1} \mathrm{H}-$ n.m.r. $\left(\mathrm{Me}_{2} \mathrm{SO}-d_{6}\right): \delta 8.37$ (s, $\left.1 \mathrm{H}, \mathrm{H}-8\right), 8.21$ (s, $\left.1 \mathrm{H}, \mathrm{H}-2\right), 5.90$ (d, $1 \mathrm{H}, J 6.0$ $\left.\mathrm{Hz}, \mathrm{H}-1^{\prime}\right), 5.45$ (d, $\left.1 \mathrm{H}, J 6.2 \mathrm{~Hz}, \mathrm{HO}-2^{\prime}\right), 5.38$ (t, $\left.1 \mathrm{H}, J 4.8 \mathrm{~Hz}, \mathrm{HO}-5^{\prime}\right), 5.20$ (d, $\left.1 \mathrm{H}, J 4.65 \mathrm{~Hz}, \mathrm{HO}-3^{\prime}\right), 4.55\left(\mathrm{~m}, 1 \mathrm{H}, \mathrm{H}-2^{\prime}\right), 4.15\left(\mathrm{~m}, 1 \mathrm{H}, \mathrm{H}-3^{\prime}\right), 3.96(\mathrm{~m}, 1 \mathrm{H}$, $\left.\mathrm{H}-4^{\prime}\right), 3.52-3.7$ (m, $\left.2 \mathrm{H}, \mathrm{H}-5^{\prime}\right)$, and 3.34 (d, $6 \mathrm{H}, \mathrm{NMe}_{2}$ ).

$5^{\prime}$-Chloro-5'-deoxy- $\mathrm{N}^{6}, \mathrm{~N}^{6}$-dimethyladenosine (3). - This compound was prepared by the method of Ichino ${ }^{8}$. Thionyl chloride $(4.0 \mathrm{~mL})$ was dissolved in hexamethylphosphoric triamide $(25 \mathrm{~mL})$ and to the solution was added $N^{6}, N^{6}$-dimethyladenosine $(2,2.5 \mathrm{~g}, 8.47 \mathrm{mmol})$. The mixture was stirred at room temperature for $15 \mathrm{~h}$, and then poured into water $(100 \mathrm{~mL})$ and concentrated in vacuo to $20 \mathrm{~mL}$. This solution was made neutral $\left(\mathrm{pH} \mathrm{8.0)}\right.$ with $2 \mathrm{M} \mathrm{NH}_{4} \mathrm{OH}$. The precipitated product was filtered off, washed with cold water, and dried to yield $2.0 \mathrm{~g}(74.5 \%)$ of 3; m.p. $150-151^{\circ}$ (lit. ${ }^{3}$ m.p. $150-151^{\circ}$ ); ${ }^{1} \mathrm{H}$-n.m.r. $\left(\mathrm{Me}_{2} \mathrm{SO}-d_{6}\right)$ : $\delta 8.26$ (s, $1 \mathrm{H}$, H-8), 8.20 (s, $1 \mathrm{H}, \mathrm{H}-2), 6.08$ (d, $\left.1 \mathrm{H}, J 5.0 \mathrm{~Hz}, \mathrm{H}-1^{\prime}\right), 5.40(\mathrm{~m}, 2 \mathrm{H}, \mathrm{OH}), 4.70$ (m, $\left.1 \mathrm{H}, \mathrm{H}-4^{\prime}\right), 4.28\left(\mathrm{~m}, 2 \mathrm{H}, \mathrm{H}-2^{\prime}\right.$ and $\mathrm{H}^{\prime} 3^{\prime}, 3.92\left(\mathrm{~m}, 2 \mathrm{H}, \mathrm{H}-5^{\prime}\right)$, and $3.45(\mathrm{~s}, 6$ $\mathrm{H}, \mathrm{NMe}_{2}$ ).

S-( $\mathrm{N}^{6}, \mathrm{~N}^{6}$-Dimethyladenosyl)-L-homocysteine (4). - A suspension of 5'chloro-5'-deoxy- $N^{6}, N^{6}$-dimethyladenosine $(3,0.63 \mathrm{~g}, 2.0 \mathrm{mmol})$, potassium iodide $(10 \mathrm{mg})$, and the sodium salt of L-homocysteine $(0.480 \mathrm{~g}, 2.5 \mathrm{mmol})$ was boiled under reflux in water $(7 \mathrm{~mL})$ for $2 \mathrm{~h}$. The mixture became clear and t.l.c. (Avicel F, $250 \mu \mathrm{m}, 9: 5$ 1-propanol-water) showed the absence of any $5^{\prime}$-chloro-5'deoxynucleoside. The mixture was allowed to cool and made acidic with $1 \mathrm{M} \mathrm{HCl}$. The solution was then applied directly to a column of Dowex 50X 4-200 $\left(\mathrm{NH}_{4}^{+}\right)$ resin $(125 \mathrm{~mL})$. The column was washed thoroughly with water $(200 \mathrm{~mL})$ and then eluted with $\mathrm{M} \mathrm{NH}_{4} \mathrm{OH}$. The eluate was evaporated to low volume in vacuo and lyophilized. The product was recrystallized from ethanol-water to give $0.38 \mathrm{~g}$ (45\%); m.p. 228-230 (lit. ${ }^{3}$ m.p. $70^{\circ}$ ); $[\alpha]_{\mathrm{D}}^{23}+37.9^{\circ}$ (c 1, 0.2M HCl); ${ }^{1} \mathrm{H}-n . m . r$. $\left(\mathrm{D}_{2} \mathrm{O}\right): \delta 8.06(\mathrm{~s}, 1 \mathrm{H}, \mathrm{H}-8), 7.94(\mathrm{~s}, 1 \mathrm{H}, \mathrm{H}-2), 5.87\left(\mathrm{~d}, 1 \mathrm{H}, J 4.9 \mathrm{~Hz}, \mathrm{H}-1^{\prime}\right), 4.25$ (t, $\left.1 \mathrm{H}, J 5.2 \mathrm{~Hz}, \mathrm{H}-3^{\prime}\right), 4.19\left(\mathrm{~m}, 1 \mathrm{H}, \mathrm{H}-4^{\prime}\right), 3.68(\mathrm{t}, 1 \mathrm{H}, J 5.6 \mathrm{~Hz}, \alpha \mathrm{C}-\mathrm{H}), 3.19$ (s, $\left.6 \mathrm{H}, \mathrm{NMe}_{2}\right), 2.81\left(\mathrm{~m}, 2 \mathrm{H}, \mathrm{H}-5^{\prime}\right), 2.55(\mathrm{t}, 2 \mathrm{H}, J 7.5 \mathrm{~Hz}, \gamma \mathrm{C}-\mathrm{H})$, and $2.02(\mathrm{~m}, 2$ $\mathrm{H}, \beta \mathrm{C}-\mathrm{H}) ; \mathrm{H}^{\prime} 2^{\prime}$ overlaps with $\mathrm{H}_{2} \mathrm{O}$ peak.

Anal. Calc. for $\mathrm{C}_{16} \mathrm{H}_{24} \mathrm{~N}_{6} \mathrm{O}_{5} \mathrm{~S}$ : C, 46.59; $\mathrm{H}, 5.86$. Found: C, 46.41; $\mathrm{H}, 5.79$.

$( \pm) \mathrm{S}-\left(\mathrm{N}^{6}, \mathrm{~N}^{6}\right.$-Dimethyladenosyl $)$-L-methionine (5). - This compound was prepared by the following modification of the procedure of Monem ${ }^{10}$. To a solution of $S$-( $N^{6}, N^{6}$-dimethyladenosyl)-L-homocysteine $(4,100 \mathrm{mg}, 0.25 \mathrm{mmol})$ in $1 \mathrm{~mL}$ of $1: 1(\mathrm{v} / \mathrm{v})$ acetic acid- $98 \%$ formic acid was added successively $0.3 \mathrm{~mL}(5.5 \mathrm{mmol})$ of iodomethane and $1.8 \mathrm{mmol}$ of silver acetate. The mixture was stirred for $4 \mathrm{~h}$ at room temperature. The resulting slurry was centrifuged to remove the precipitated silver iodide and the acetic acid-formic acid solution was diluted with water $(2 \mathrm{~mL})$ and extracted with ether $(3 \times 20 \mathrm{~mL})$ to remove the excess of iodomethane. The aqueous solution was purged with nitrogen to remove any excess of ether and loaded onto $\mathrm{a} \mathrm{C}_{18}$ reverse-phase column operating under low pressure. The product was eluted with $0.1 \mathrm{M}$ ammonium acetate. Fractions containing the product were 
pooled and lyophilized to give $5(93 \mathrm{mg}, 73 \%) ;{ }^{1} \mathrm{H}$-n.m.r. $\left(\mathrm{D}_{2} \mathrm{O}\right) ; \delta 8.06(\mathrm{~s}, 1 \mathrm{H}$, H-8), 8.0 (s, $1 \mathrm{H}, \mathrm{H}-2$ ), 5.89 (d, $1 \mathrm{H}, J 4.9 \mathrm{~Hz}, \mathrm{H}^{\prime} \mathbf{1}^{\prime}$ ), 4.67 (bs, $\left.1 \mathrm{H}, \mathrm{H}-2^{\prime}\right), 4.36$ (t, $\left.1 \mathrm{H}, J 5.0 \mathrm{~Hz}, \mathrm{H}-3^{\prime}\right), 3.76\left(\mathrm{~m}, 1 \mathrm{H}, \mathrm{H}-4^{\prime}\right), 3.52$ (bs, $\left.1 \mathrm{H}, \alpha \mathrm{C}-\mathrm{H}\right), 3.23(\mathrm{~s}, 6 \mathrm{H}$, $\left.\mathrm{NMe}_{2}\right), 3.55\left(\mathrm{~m}, 2 \mathrm{H}, \mathrm{H}-5^{\prime}\right), 2.77(\mathrm{~m}, 2 \mathrm{H}, \gamma \mathrm{C}-\mathrm{H}),\left[2.79\left(\mathrm{~s}, 1.2 \mathrm{H}, \mathrm{SCH}_{3}\right), 2.75(\mathrm{~s}\right.$, $\left.\left.1.8 \mathrm{H}, \mathrm{SCH}_{3}\right)\right]^{*}$, and $2.16(\mathrm{~m}, 2 \mathrm{H}, \beta \mathrm{C}-\mathrm{H})$. The residual solid was immediately dissolved in $1.0 \mathrm{mM} \mathrm{HCl}$ and stored at $-20^{\circ}$.

\section{ACKNOWLEDGMENT}

This work was supported by U.S. Public Health Service Grant GM-30097.

\section{REFERENCES}

1 R. W. Woodard in E. Usdin, R. T. Borchard, and C. R. Creveling (Eds.), 1-Aminocyclopropane-1-carboxylic acid synthase, A Unique SAM-Utilizing Enzyme, in Biochemistry of SAdenosylmethionine and Related Compounds, Macmillan, 1982, pp. 621-625.

2 R. T. Borchard, Y. S. Wu, J. A. Huber, and A. F. Wycpalek, J. Med. Chem., 19 (1976) $1104-1110$.

3 R. T. Borchardt, J. A. Huber, AND Y. S. Wu, J. Med. Chem., 19 (1976) 1094-1099.

4 J. ZemulCKa And F. Sorm, Coll. Czech. Chem. Commun., 30 (1965) 1880-1889.

5 J. Zemlička, S. Cilladek, D. Ringer, And K. Quiggle, Biochemistry, 14 (1975) 5239-5249.

6 M. Morr and L. ERnSt, J. Chem. Res. Synop., (1981) 90-91.

7 K. K. Ogilvie, S. L. Beaucage, M. F. Gillen, and D. W. Entwistle, Nucleic Acid Res., 6 (1979) 2261-2273.

8 K. Kikugawa and M. Ichino, Tetrahedron Lett., 2 (1971) 87-90.

9 K. Ramalingam and R. W. Woodard, J. Org. Chem., 49 (1984) 1291-1293.

10 M. Pankaskie and M. A. Monem, J. Med. Chem., 23 (1980) 121-127.

11 M. L. Stolowitz And M. J. Minch, J. Am. Chem. Soc., 103 (1981) 6015-6019.

*The methylation of all $S$-adenosyl-L-homocysteine derivatives studied to date ${ }^{11}$ has given a mixture of stereoisomers, at the sulfur center, in which the unnatural $R$ isomer is produced in $20 \%$ enantiomeric excess. This deviation from the expected racemic mixture $(50 \% R: 50 \% S$ at the sulfur center) is probably due to asymmetric induction by the ribose portion of the nucleoside or another adjacent chiral center. 